\title{
EFFECTS OF GARLIC, RAMSON AND ONION (ALLIUM SATIVUM, ALLIUM URSINUM, ALLIUM CEPA) ON PERFORMANCE AND GUT BACTERIA POPULATION IN BROILER CHICKENS
}

\author{
Tamer Tashla ${ }^{1}$, Nikola Puvača ${ }^{1}$, Nedeljka Nikolova ${ }^{2}$, Ivana Čabarkapa ${ }^{3}$, \\ Sanja Popović ${ }^{3}$, Radivoj Prodanović ${ }^{\text {, Jovanka Lević }}$ \\ ${ }^{I}$ Department of Engineering Management in Biotechnology, \\ Faculty of Economics and Engineering Management, University Business Academy, \\ Cvećarska 2, 21000 Novi Sad, Serbia \\ ${ }^{2}$ Institute of Animal Science, University "Ss. Cyril and Methodius", \\ Blvd. Ilinden 92/a, 1000 Skopje, North Macedonia \\ ${ }^{3}$ Scientific Institute of Food Technology, University of Novi Sad, \\ Blvd. Cara Lazara 1, 21000 Novi Sad, Serbia \\ nikola.puvaca@gmail.com
}

\begin{abstract}
A b s tra c t: The aim of the experiment was to investigate the effects of garlic (Allium sativum L.), ramson (Allium ursinum L.) and onion (Allium cepa L.) on the growth performance and gut bacteria population in broiler chickens. A total of 288 one day old broiler chicks of hybrid line Ross 308 of both sexes, were weighed and randomly allocated to four dietary treatments, each with 6 replicate pens of 12 chicks. The dietary treatments consisted of the basal diet as control treatment (C), control $+5 \mathrm{~g} / \mathrm{kg}$ of garlic powder (A1), control $+5 \mathrm{~g} / \mathrm{kg}$ of ramson powder (A2) and control +5 $\mathrm{g} / \mathrm{kg}$ of onion (A3), respectively. The dietary supplementation of $5 \mathrm{~g} / \mathrm{kg}$ of onion (A3) increased the final body weight of broilers at 42 days of age compared to the other experimental treatments ( $\mathrm{p}<0.05)$. The feed intake during starting, growing and the entire experimental period was higher for broilers supplemented with $5 \mathrm{~g} / \mathrm{kg}$ of onion compared with control chickens and the chickens supplemented with garlic and ramson powder $(\mathrm{p}<0.05)$. The Lactobacilli spp. population in chickens supplemented with onion was significantly higher compared to other dietary treatments at the end of the experiment $(\mathrm{p}<0.05)$. The lowest Escherichia coli loads were detected in broilers fed diets with the addition of garlic powder. The E. coli loads significantly decreased in broilers fed diets with the addition of ramson and onion powder ( $p<0.05$ ). It can be concluded that the addition of onion to broiler chicken nutrition in the concentration of 5 $\mathrm{g} / \mathrm{kg}$ of complete feed, could induce favourable influences on the performance and ileum bacteria population.
\end{abstract}

Key words: herbs; medicinal plants; chickens; nutrition

\section{ВЛИЈАНЕ НА ЛУКОТ, ДИВИОТ ЛУК И КРОМИДОТ (ALLIUM SATIVUM, ALLIUM URSINUM, ALLIUM CEPA) ВРЗ ПЕРФОРМАНСИТЕ И ПОПУЛАЦИЈАТА НА ЦРЕВНИТЕ БАКТЕРИИ КАЈ БРОЈЛЕРСКИТЕ ПИЛИЫА}

A п с т р а к т: Целта на експериментот беше да се испита влијанието на лукот (Allium sativum L.), дивиот лук (Allium ursinum L.) и кромидот (Allium cepa L.) врз перформансите на растот и на популацијата на цревните бактерии кај бројлерските пилиња. Вкупно 288 еднодневни бројлерски пилиња од хибридната линија рос 308 , од двата пола, биле измерени и случајно распределени во четири третмани на исхрана, секој со 6 повторувања со по 12 пилиња. Третманите се состоеле од основна храна како контролен третман (C), контролна $+5 \mathrm{~g} / \mathrm{kg}$ лук во прав (A1), контролна $+5 \mathrm{~g} / \mathrm{kg}$ див лук во прав (А2) и контролна $+5 \mathrm{~g} / \mathrm{kg}$ кромид во прав (А3), соодветно. Додавањето на $5 \mathrm{~g} / \mathrm{kg}$ кромид во прав (А3) значајно ја зголемило финалната телесна тежина кај бројлерите на 42-дневната возраст во споредба со другите експериментални третмани ( $<<0,05)$. Внесот на храна уште од стартот, во текот на растењето и во целиот експериментален период и беше поголем кај бројлерите кои добивале дополнително $5 \mathrm{~g} / \mathrm{kg}$ кромид во прав во споредба со контролните пилиња и пилињата кои дополнително се хранеле со лук и див лук во прав ( $<<0,05)$. Популацијата Lactobacilli spp. кај пилињата кои дополнително добивале кромид во прав на крајот од експериментот била значително повисока во споредба со 
другите третмани на исхрана ( $<<0,05)$. Најниски оптоварувања со Escherichia coli биле откриени кај бројлерите кои се хранеле со смеса во која е додаван лук во прав. Оптоварувањето со E. coli значително се намали кај бројлерите хранети со смеса во која е додаван див лук или кромид во прав ( $<0,05)$. Може да се заклучи дека додавањето на кромид во прав во исхраната на бројлерски пилиња во концентрација од $5 \mathrm{~g} / \mathrm{kg}$ во целата храна може да предизвика поволни влијанија врз перформансите и популацијата на бактериите во тенкото црево.

Клучни зборови: билки; лековити растенија; пилиња, исхрана

\section{INTRODUCTION}

In the past three decades, the antibiotic growth promoters were used in the poultry industry worldwide with the goal of promoting the productive performance of birds and to protect flock health status $[9,10,14]$. The antibiotic growth promoters were supposed to increase the growth rate as a result of improved gut health resulting in better nutrient utilization and decreased feed conversion ratio [12]. On the other hand, the usage of dietary antibiotics resulted in numerous problems such as the development of antibiotic-resistant bacteria, and drug residue in the final products such as meat and eggs, which are harmful to the consumers [5, 7]. Thus, the use of antibiotics as growth promoters was forbidden in the European Union countries in January 2006 [4]. As the consequence, it became necessary to develop alternative natural substances and strategies for poultry growth enhancers and possible disease prevention $[11,13]$.

Phytogenic and herbal products, also known as phytobiotic products which are plant-derived products, used in animal feeding to improve the performance through amelioration of feed properties, the promotion of production performance and the improvement of the quality of animal origin food [1, 2]. The genus Allium includes about 550 species. A few of these are important as food plants and as drugs in folk medicine, but the most important of them are garlic [16], ramson and onion [6]. This allium plants are bulbous plants widely cultivated in almost every country of the world with the leading production in China and India [13, 16]. Allium sp. bulbs possess numerous organic sulphur compounds such as alliin, allyl methyl thiosulfonate, 1propenyl allyl thiosulfonate, $\gamma-1$ glutamyl-s-alkyllcysteine, trans-s-(1-propenyl) cysteine sulfoxide, smethyl-cysteine sulfoxide, spropylcycteine sulfoxides and cycloallicin, flavonoids, phenolic acids, sterols including cholesterol, stigmasterol, b-sitosterol, saponins and a trace of volatile oil compounds $[3,15]$. Most of the plant parts contain compounds with proven antibacterial, antiviral, antiparasitic, antifungal properties and have antihypertensive, hypoglycemic, antithrombotic, antihyperlipidemic, anti-inflammatory and antioxidant activity. Puvača et al. $[10,11]$ observed the beneficial influence of garlic on the growth performance of broiler chickens, but the effect of Allium sp. on the performance and intestinal microflora in broiler chickens is still not completely investigated.

Therefore the present study was designed to compare the efficacy of three Allium sp. plants on the growth performance and ileum microflora in broiler chickens nutrition.

\section{MATERIAL AND METHODS}

\section{Chickens and dietary treatments}

The biological experiment with broiler chickens was performed in accordance with the EU legislation and principle of the Three Rs within Directive 2010/63/EU. Two hundred and eightyeight one day old broiler chickens of hybrid line Ross 308, of both sexes were weighed and randomly assigned to the 4 dietary treatments, each with 6 replicate pens of 12 chicks. The dietary treatments consisted of the basal diet as a control treatment (C), control $+5 \mathrm{~g} / \mathrm{kg}$ of garlic powder (A1), control +5 $\mathrm{g} / \mathrm{kg}$ of ramson powder (A2) and control $+5 \mathrm{~g} / \mathrm{kg}$ of onion (A3), respectively (Table 1).

\section{Table 1}

Experimental dietary treatman design

\begin{tabular}{lcccc}
\hline \hline \multirow{2}{*}{ Allium sp. } & \multicolumn{4}{c}{$\begin{array}{c}\text { Dietary treatments } \\
(\mathrm{g} / \mathrm{kg} \text { on top })\end{array}$} \\
\hline Garlic (Allium sativum L.) & 0.0 & 5.0 & 0.0 & 0.0 \\
Ramson (Allium ursinum L.) & 0.0 & 0.0 & 5.0 & 0.0 \\
Onion (Allium cepa L.) & 0.0 & 0.0 & 0.0 & 5.0 \\
\hline \hline
\end{tabular}

The basal diet was formulated according to the nutrient requirements of broilers provided by Aviagen ${ }^{\circledR}$. The chickens were fed with a first phase diet from 0 to 21 day of age and second phase diet from 22 to 42 day of age. Each Allium sp. was added to the basal diets on top in the concentration of $5 \mathrm{~g} / \mathrm{kg}$. The chicks were raised on floor pens with the chopped straw as bedding for 42 days, while feed and water throughout the entire experimental period 
were provided ad libitum. The lighting regime consisted of a period of $23 \mathrm{~h}$ light and $1 \mathrm{~h}$ of darkness. The ambient temperature in the experimental house was maintained at $32^{\circ} \mathrm{C}$ during the first week and gradually decreased by $3^{\circ} \mathrm{C}$ in the second and third week, and thereafter fixed at $22^{\circ} \mathrm{C}$.

\section{Productive performance}

The body weights of broilers were recorded on $1^{\text {st }}, 21^{\text {st }}$ and $42^{\text {nd }}$ day of age. The feed intake and weight gain were recorded in different periods and while feed conversion ratio (FCR) was calculated. The mortality was recorded as it occurred and was used to adjust the total number of chickens to determine the total feed intake per chicken as well as FCR.

\section{Enumeration of bacteria populations in ileum}

The intestinal samples were collected and fresh digesta samples from ileum were taken for the bacterial analyses within an hour from the collection. The digesta samples were serially diluted in $0.85 \%$ sterile saline solution for enumeration of Lactobacilli spp. and Escherichia coli by conventional microbiological techniques using the selective agar media. All the microbiological analyses were performed in duplicates and the average values were used for statistical analysis. Lactobacilli spp. were anaerobically assayed using MRS agar (Fluka 80961). E. coli were enumerated through the use of Plate Count MUG Agar (Fluka 80961) and TBX Agar (Fluka 92435). The results were expressed as base $^{-10}$ logarithm colony-forming units per gram of ileal.

\section{Statistical analyses}

The statistical analyses were conducted using the Statistica statistical package program (version 13) to determine if the variables differed between treatments. The significant effects were explored using analysis of variance (ANOVA), LSM and Fisher's LSD post-hoc multiple range test to ascertain differences among treatment means. The significance level of $\mathrm{p}<0.05$ was used.

\section{RESULTS AND DISCUSSION}

\section{Productive performance}

The effects of dietary treatments on the growth performance are presented in Table 2. The dietary supplementation of onion increased the body weight and feed intake of chickens at different growth periods. The chickens receiving ramson and onion had lower FCR compared to the chickens fed with garlic during the first dietary phase $(p<0.05)$, but FCR of the chickens in other periods was not affected ( $p>$ 0.05). The positive effect of the onion on the feed utilization was observed at the first phase period, but the improved FCR obtained in chickens supplemented with onion was not reflected at the second phase period probably due to the facts that the older birds nutrient requirements decrease with age and also they have better developed digestive tracts and organs. The improved growth performance of chicks receiving onion could be due to the content of the organosulphur compounds of onion.

\section{Table 2}

\section{Productive performance of chickens fed dietary allium sp. powder}

\begin{tabular}{|c|c|c|c|c|c|}
\hline \multirow{2}{*}{ Parameters } & \multicolumn{4}{|c|}{ Dietary treatments (g/kg on top) } & \multirow{2}{*}{ SEM } \\
\hline & $\mathrm{C}$ & A1 & $\mathrm{A} 2$ & $\mathrm{~A} 3$ & \\
\hline \multicolumn{6}{|c|}{ Feed consumption (g/chicken/day) } \\
\hline 0 to $21^{\text {st }}$ day & $32.3^{\mathrm{ab}}$ & $32.3^{\mathrm{ab}}$ & $30.3^{\mathrm{b}}$ & $33.5^{\mathrm{a}}$ & 0.52 \\
\hline $21^{\text {st }}$ to $42^{\text {nd }}$ day & $123.4^{\mathrm{b}}$ & $125.4^{\mathrm{b}}$ & $129.8^{\mathrm{ab}}$ & $134.4^{\mathrm{a}}$ & 1.04 \\
\hline 0 to $42^{\text {nd }}$ day & $94.0^{\mathrm{b}}$ & $95.0^{\mathrm{b}}$ & $95.2^{\mathrm{ab}}$ & $100.7^{\mathrm{a}}$ & 0.83 \\
\hline \multicolumn{6}{|c|}{ Feed conversion ratio $(\mathrm{kg} / \mathrm{kg})$} \\
\hline 0 to $21^{\text {st }}$ day & $1.5^{\mathrm{ab}}$ & $1.6^{\mathrm{a}}$ & $1.5^{\mathrm{b}}$ & $1.5^{\mathrm{b}}$ & 0.009 \\
\hline $21^{\text {st }}$ to $42^{\text {nd }}$ day & $1.9^{\mathrm{a}}$ & $1.9^{\mathrm{a}}$ & $1.9^{\mathrm{a}}$ & $1.9^{\mathrm{a}}$ & 0.012 \\
\hline 0 to $42^{\text {nd }}$ day & $1.8^{\mathrm{a}}$ & $1.8^{\mathrm{a}}$ & $1.8^{\mathrm{a}}$ & $1.8^{\mathrm{a}}$ & 0.092 \\
\hline \multicolumn{6}{|c|}{ Body weight (kg) } \\
\hline $21^{\text {st }}$ day & $0.47^{\mathrm{a}}$ & $0.64^{\mathrm{a}}$ & $0.45^{\mathrm{a}}$ & $0.48^{\mathrm{a}}$ & 0.004 \\
\hline $42^{\text {nd }}$ day & $1.84^{\mathrm{b}}$ & $1.85^{\mathrm{b}}$ & $1.86^{\mathrm{b}}$ & $1.96^{\mathrm{a}}$ & 0.023 \\
\hline
\end{tabular}

Treatments with different letter indexes in the same row are statistically significantly different $(\mathrm{p}$ $<0.05)$

\section{Bacteria populations in ileum}

The results on ileum bacteria populations of broiler chicks at the end of the experiment are presented in Table 3. The Lactobacilli spp. population in chickens supplemented with onion was significantly higher $(\mathrm{p}<0.05)$ compared to the control and ramson treatment, and $E$. coli loads were significantly lower $(\mathrm{p}<0.05)$ than other treatments on $42^{\text {nd }}$ day of age. The lowest E. coli loads were observed in chickens fed diets containing garlic powder. The 
antimicrobial activity of allium sp. was recorded as very effective against Vibrio cholerae [6]. Also, researchers have recorded that allium $s p$. ethanol extract induced 9 and $11 \mathrm{~mm}$ zone of inhibition with Minimum Inhibitory Concentration (MIC) 0.8 $\mathrm{mg} / \mathrm{ml}$ against Pseudomonas aeruginosa $[6,8]$. The MIC values were determined by the disc diffusion method [8].

Treatments with different letter indexes in the same row are statistically significantly different $(\mathrm{p}$ $<0.05)$.
Table 3

\section{Effects of dietary treatments on ileum bacteria} populations of broiler chicks

\begin{tabular}{llllll}
\hline \hline \multirow{2}{*}{ Bacteria } & \multicolumn{5}{c}{ Dietary treatments (g/kg on top) } \\
\cline { 2 - 6 } & C & A1 & A2 & A3 & \\
\hline \hline Lactobacilli spp. & $5.83^{\mathrm{d}}$ & $6.41^{\mathrm{ab}}$ & $5.92^{\mathrm{dc}}$ & $6.57^{\mathrm{a}}$ & 0.17 \\
E. coli & $8.01^{\mathrm{a}}$ & $6.17^{\mathrm{d}}$ & $7.64^{\mathrm{b}}$ & $7.19^{\mathrm{c}}$ & 0.03 \\
\hline
\end{tabular}

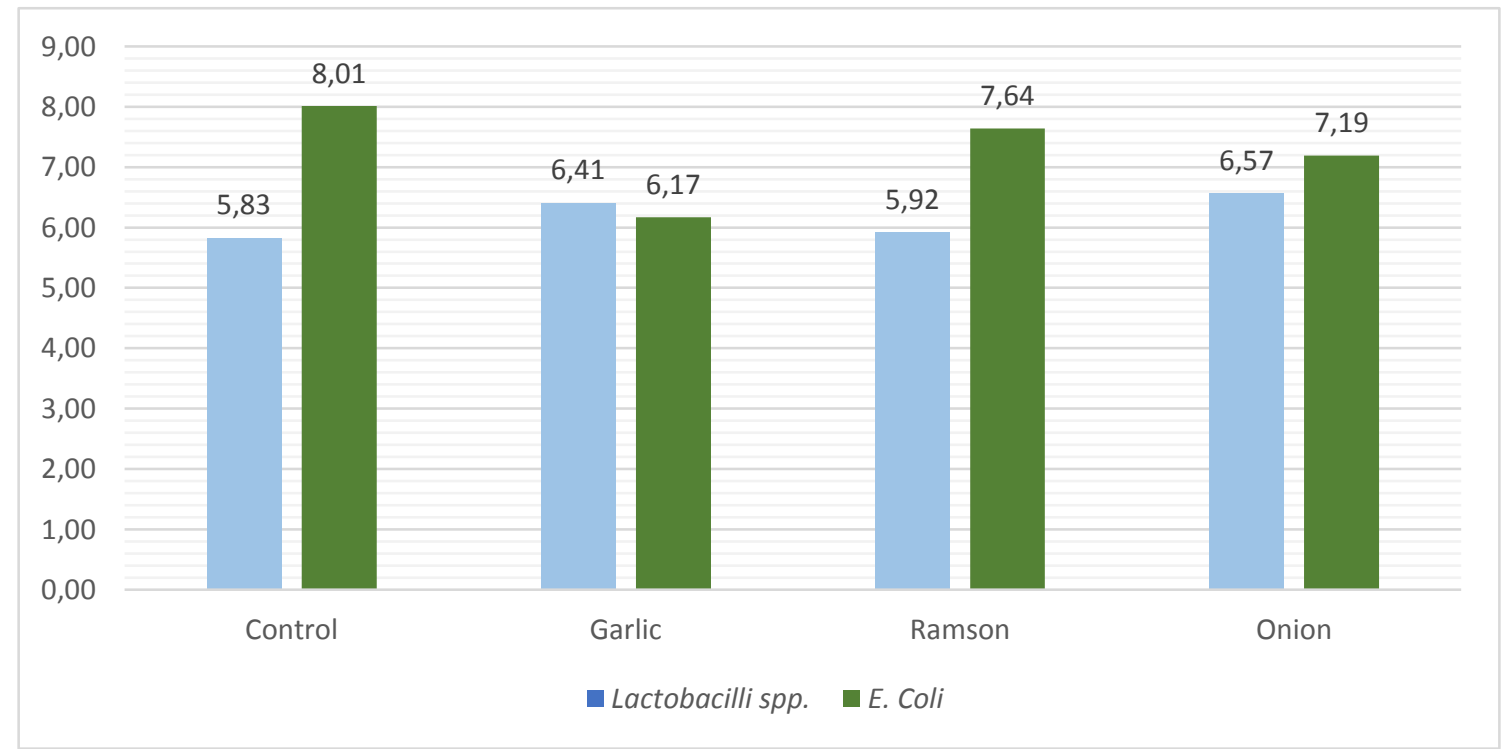

Fig. 1. Effects of dietary treatments on ileum bacteria populations of broiler chicks

The results presented in Table 3 and Figure 1, with certainty show the positive influence of dietary addition of garlic, ramson and onion to broiler chicken nutrition. The addition of this Allium sp. has led to a decreasing number of E. coli population in the gastrointestinal tract while the population of Lactobacilli spp. has been increased, which indicates the positive influence of this natural herbal additives.

\section{CONCLUSIONS}

Based on the obtained results this study showed that garlic (Allium sativum L.), ramson (Allium ursinum L.) and onion (Allium cepa L.) exhibited positive effects on the performance and ileum bacteria population, but further experiments with these plants in chickens nutrition are more than necessary.
Acknowledgements: This paper is a part of the project III 46012 which is financed by Ministry of Education, Science and Technological Development of Republic of Serbia.

\section{REFERENCES}

[1] Alder, A. J., Holub, B. J.: Effect of garlic and fish-oil supplementation on serum lipid and lipoprotein concentrations in hypercholesterolemic men. Am. J. Clin. Nutr., 65, 445450 (1997)

[2] Amagase, H., Petesch, B., Matsuura, H., Kasuga, S., Itakura, Y.: Intake of garlic and its bioactive components. J. Nutr., 131 (95), 5S-62S (2001).

[3] Amagase, H.: Clarifying the real bioactive constituents of garlic. J. Nutr., 136 (3), 716S-725S (2006).

[4] Castanon, J. I. R.: History of the use of antibiotic as growth promoters in European poultry feeds. Poult. Sci., 86, 24662471 (2007).

[5] Demir, E., Sarica, S., Ozcan M. A., Suicmez, M.: The use of natural feed additives as alternatives for an antibiotic 
growth promoter in broiler diets. Brit. Poultry Sci., 44, S44-S45 (2003).

[6] Hannan, A., Hunayun, T., Hussain, M. B., Yasir, M., Sikandar, S.: In vitro antibacterial activity of onion (Allium сера) against clinical isolates of vibrio cholera. J. Ayub. Med. Coll. Abbottabad., 22, 160-163 (2010).

[7] Kostadinović, Lj., Puvača, N., Popović, S., Lević, J.: Botanical supplements as anticoccidial alternatives in poultry nutrition. World Poultry Sci. J., 71 (1), 27-35 (2015).

[8] Melvin, J. M., Jayochitra, J., Vijayapriaya, M.: Antimicrobial activity of some common spices against certain human pathogens. J. Med. Plants. Res., 3, 1134-1136 (2009).

[9] Popović, S., Kostadinović, Lj., Đuragić, O., Aćimović, M., Čabarkapa, I., Puvača, N., Ljubojević Pelić, D.: Influence of medicinal plants mixtures (Artemisia absinthium, Thymus vulgaris, Menthae piperitae and Thymus serpyllum) in broilers nutrition on biochemical blood status. J. Agron. Technol. Eng. Manag., 1 (1), 91-98 (2018).

[10] Puvača, N., Kostadinović, Lj., Ljubojević, D., Lukač, D., Lević, J., Popović, S., Novakov, N., Vidović, B., Đuragić, O.: Effect of garlic, black pepper and hot red pepper on productive performances and blood lipid profile of broiler chickens. Europ. Poult. Sci., 79, 1-13 (2015).

[11] Puvača, N., Kostadinović, Lj., Popović, S., Lević J., Ljubojević, D., Tufarelli, V., Jovanović, R., Tasić, T., Ikonić, P., Lukač, D.: Proximate composition, cholesterol concentration and lipid oxidation of meat from chickens fed dietary spice addition (Allium sativum, Piper nigrum, Capsicum annuum). Anim. Prod. Sci., 56 (11), 1920-1927 (2016).

[12] Puvača, N., Ljubojević, D., Kostadinović, Lj., Lukač, D., Lević, J., Popović S., Đuragić, O.: Spices and herbs in broilers nutrition: Effects of garlic (Allium sativum L.) on broiler chicken production. World Poultry Sci. J., 71 (3), 533-538 (2015).

[13] Puvača, N., Ljubojević, D., Lukač, D., Kostadinović, Lj., Stanaćev, V., Popović, S., Živkov Baloš, M., Nikolova, N.: Digestibility of fat in broiler chickens influenced by dietary addition of spice herbs. Maced. J. Anim. Sci., 4 (2), 61-67 (2014).

[14] Puvača, N., Stanaćev, V., Glamočić, D., Lević, J., Perić, L., Stanaćev, V., Milić, D.: Beneficial effects of phytoadditives in broiler nutrition. World Poultry Sci. J., 27-34 (2013).

[15] Puvača, N.: Bioactive compounds in selected hot spices and medicinal plants. J. Agron. Technol. Eng. Manag., 1 (1), 8-17 (2018).

[16] Stanaćev, V., Glamočić, D., Milošević, N., Perić, L., Puvača, N., Stanaćev, V., Milić, D., Plavša, N.: Influence of garlic (Allium sativum L.) and copper as phytoadditives in the feed on the content of cholesterol in the tissues of the chickens. J. Med. Plants Res., 6 (14), 2816-2819 (2012). 
